\title{
Global Contamination from Uranium: Insights into Problem Based on the Uranium Content in the Human Prostate Gland
}

\author{
Vladimir Zaichick $^{1 *}$, Sofia Zaichick ${ }^{1,2}$ \\ ${ }^{1}$ Department of Radionuclide Diagnostics, Medical Radiological Research Centre, Kaluga Region, Russia \\ ${ }^{2}$ Department of Medicine, University of Illinois College of Medicine, Chicago, IL USA
}

"Corresponding Author: : Dr. Vladimir Zaichick, Professor, Medical Radiological Research Centre, 4, Koroleyva St., Obninsk 249036, Kaluga Region, Russia, Tel: (48439) 60289, Fax: (495) 956 1440; E-mail: vezai@obninsk.com

\begin{abstract}
The problem of global contamination from uranium (U) is a difficult task. The present investigation was aimed to study the possibilities of using prostate tissue as a biological material for global environmental monitoring of $U$. The $U$ content in non-hypertrophic prostate of apparently healthy 64 residents of uncontaminated territory was measured by instrumental neutron activation analysis and inductively coupled plasma mass spectrometry. Mean values $(\mathrm{M} \pm \mathrm{SEM})$ for the mass fraction of $\mathrm{U}$ in prostate of all subjects taken together was $0.0049 \pm 0.0014 \mathrm{mg} / \mathrm{kg}$ of dry tissue. In order to estimate the effect of age on the investigated parameter we used three age groups: 13-20 years, 21-40 years, and 41-60 year. Mean values ( $\mathrm{M} \pm \mathrm{SEM}$ ) for the mass fraction of $U(\mathrm{mg} / \mathrm{kg}$ of dry tissue) in age groups were as follows: 0.0023 $\pm 0.0007,0.0021 \pm 0.0005$, and $0.0077 \pm 0.0026$, respectively. For the first time statistically significant ( $\mathrm{p} \leq 0.05$, $\mathrm{t}$ - test) and exponential increase of the $\mathrm{U}$ content in prostate tissue with age was observed. It was shown also that the $U$ content in the human prostate is higher than a level of element content in the bone, skeletal muscle, liver, and whole blood. No significant inverse correlation between the $U$ content and contents of other trace element in prostate was observed. Finally, it was concluded that the prostate is a target organ for $U$ in human body and can be used as a biological material for global environmental monitoring of $U$.
\end{abstract}

Received date: December 13, 2015

Accepted date: December 18, 2015

Published date: December 22, 2015

Citation: Zaichick, V., et al. Global Contamination from Uranium: Insights into Problem Based on the Uranium Content in the Human Prostate Gland. (2015) J Environ Health Sci 1(4): 1-5.

DOI: $10.15436 / 2378-6841.15 .26$

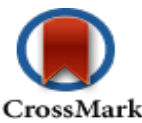

Keywords: Global contamination from uranium; Human prostate; Age-related changes; INAA; ICP-MS

\section{Introduction}

Uranium (U) is found in the environment as naturally occurring chemical element and as products or by-products of nuclear technologies. $U$ is the heaviest known natural element with a specific density of $18.7 \mathrm{~g} / \mathrm{cm}^{3}$. It is 40 times more common in nature than silver. There are a few important sources of $U$ to the environment: the generation of nuclear fuel from natural $U$, using ${ }^{235} \mathrm{U}$ for the production of nuclear weapons and in some nuclear reactors as a source of energy, nuclear weapon tests, stored nuclear wastes, as well as erosion of agricultural and contaminated soils ${ }^{[1]}$. All $\mathrm{U}$ isotopes are radioactive and chemically toxic. Thus, it is very important their quantity to be under control.

The problem of global contamination from $U$ has been recognized over the past decades. The search for uranium covered almost all countries in the world and as the result is a legacy of numerous mines and mills that have not been properly closed out and made safe from both a radiological as well as a general safety ${ }^{[2]}$. The environmental awareness began in the mid-1970s. This awareness was born out of the recognition of level and types of impacts that human activity, including mining, was having on the environment ${ }^{[2]}$.

An increasing awareness of the radiological and toxicological impact of the nuclear power industry and other nuclear technologies is observed now a days on general population because in addition to the nuclear power industry, depleted uranium (DU) is being used increasingly often as a component of munitions in military conflicts. Military personnel, civilians and the DU munitions 
producers are being exposed to the DU aerosols that are generated. This led to renew interest to assess the health impact of the use of U. It is well known that $U$ inhaling and ingesting affect reproductive organs and the fetus. $U$ is also a carcinogen that causes cancer and may increase the risk of leukemia and tumor of different organs including lung, bone, prostate and others ${ }^{[1,3]}$.

Among $U$ processing workers, an increase in prostate cancer mortality was often observed ${ }^{[4-8]}$. Prostate cancer mortality was increased in almost all portions of the nuclear cycle except for fuel fabrication ${ }^{[9]}$ and reprocessing activities ${ }^{[10,11]}$. Excess in prostate cancer mortality was significant in the United Kingdom Atomic Energy Authority workers monitored for contamination by tritium and other unspecified radionuclides containing $\mathrm{U}^{[12]}$. In the combined analysis of three UK nuclear industry workforces mortality from prostate cancer was elevated in workers monitored for exposure to radionuclides compared with the population of England and Wales and with an internal comparison $^{[13]}$.

Local populations living in areas, where DU weapons have been used, as well as soldiers who were on missions in the Kuwait, Balkans and Iraq, show an increase in the incidence of cancers and cancer mortality. A new study shows that U.S. military service members have double the rates of prostate cancer in comparison with general population ${ }^{[14]}$. The authors suggested prostate cancer rates have gone up as a result of troop exposure to DU.

A body of literature exists on the contamination of environmental media directly linked to consumption and therefore potential uptake of $U$ by humans, principally soils and water. In contrast there are relatively few articles that set out to quantify the level of $U$ in human tissues and fluids, which summarized all ways of $U$ intake in human body. In spite of the limited data on $\mathrm{U}$ in human body there is opinion that liver and skeleton are the target organs for $\mathrm{U}^{[15-17]}$. In the literature available to us, we found only one result on the content of $U$ measured in one human prostate ${ }^{[18]}$. As reported in this compilation, mass fraction of $\mathrm{U}$ in the human prostate is at least two-three orders of magnitude higher, than mass fraction of element in the human bone, liver and other organs and tissues ${ }^{[18]}$. If these results are correct the prostate tissue may be a target organ for $U$ and a suitable index medium for the evaluation of a low-level exposure of $U$.

Before the prostate can be applied to monitoring environmental exposure it is necessary to establish the normal level and age-related changes of $U$ in prostate. Because, the absorption of $U$ could be inhibited or stimulated by other ingested chemical elements it is interest also to investigate the age-related dynamics of $U$ content in prostate tissue in relationships with other chemical element contents investigated by us in previous studies $^{[19-30]}$.

This work had four aims. The first one was to assess the $U$ content in non-hypertrophic prostate of apparently healthy residents of uncontaminated territory using instrumental neutron activation analysis (INAA) and inductively coupled plasma mass spectrometry (ICP-MS). The second aim was to investigate the age-dynamic of $U$ content in prostate and compare the contents of $U$ in different age groups. The third aim was to compare the $U$ content in prostate with the levels of element content in some other tissues and organs of human body. The last aim was to estimate the correlations between the $U$ content and other chemical element contents in normal prostate.

\section{Materials and Methods}

\section{Sample selection}

Samples of the human prostate were obtained at postmortems from intact cadavers (64 males, 13 to 60 years old) within $48 \mathrm{~h}$ of death. The majority of deaths were due to traumas. All the deceased were citizens of Moscow. All cadavers had undergone routine autopsy at the Institute of Forensic Medicine, Moscow. All prostate glands were divided (with an anterior-posterior cross-section) into two portions using a titanium scalpel. One tissue portion was reviewed by an anatomical pathologist while the other was used for the U content determination. Only posterior part of the prostate, including the transitional, central, and peripheral zones, was investigated. A histological examination was used to control the age norm conformity as well as the unavailability of microadenomatosis and latent cancer. None of those who died a sudden death had contact with $U$ in work places and had suffered from any systematic or chronic disorders before.

\section{Sample preparation}

After the samples intended for chemical element analysis were weighed, they were transferred to $-20^{\circ} \mathrm{C}$ and stored until the day of transportation in the Medical Radiological Research Center (MRRC), Obninsk. In the MRRC all samples were freeze-dried and homogenized. The pounded samples weighing about $50 \mathrm{mg}$ were used for U analysis by INAA and ICP-MS.

The samples for INAA were wrapped separately in a high-purity aluminum foil washed with rectified alcohol beforehand and placed in a nitric acid-washed quartz ampoule. The samples for ISP-MS were decomposed in autoclaves. $1.5 \mathrm{~mL}$ of concentrated $\mathrm{HNO}_{3}$ (Nitric acid 65\%, max. 0.0000005\% $\mathrm{Hg}$, GR, ISO, Merck) and $0.3 \mathrm{~mL}$ of $\mathrm{H}_{2} \mathrm{O}_{2}$ (pure for analysis) were added to tissue samples, placed in one-chamber autoclaves (Ancon-AT2, Ltd., Russia) and then heated for $3 \mathrm{~h}$ at $160-200^{\circ} \mathrm{C}$ to decompose. After autoclaving they were cooled to room temperature and solutions from the decomposed samples were diluted with deionized water (up to $20 \mathrm{~mL}$ ) and transferred to plastic measuring bottles. Simultaneously, the same procedure was performed in autoclaves without tissue samples (only $\mathrm{HNO}_{3}+$ $\mathrm{H}_{2} \mathrm{O}_{2}+$ deionized water), and the resultant solutions were used as control samples (blank measurements).

\section{Analytical methods}

Mass fractions of $U$ in prostate samples were measured using two analytical methods: INAA and ICP-MS. Details of methods and procedures such as nuclear reactions, radionuclides, gamma-energies, isotopes, spectrometers, spectrometer parameters, and operating conditions were presented in our earlier publications concerning the elements of human bone tissue $^{[33-34]}$.

\section{Certified reference material}

Three sub-samples of the Institute of Nuclear Chemistry and Technology (INCT, Warsaw, Poland) certified reference materials CRM INCT-MPH-2 Mixed Polish Herbs were analyzed simultaneously with prostate samples to estimate the precision and accuracy of results. The samples of standard and certified reference materials were treated in the same way as the prostate tissue samples. The detailed results of quality control 
were presented in our earlier publications concerning the elements of human bone tissue ${ }^{[31-33]}$.

\section{Computer programs and statistic}

All prostate samples were prepared in duplicate and mean values of trace element contents were used in final calculation. Using the Microsoft Office Excel programs, the summary of statistics, arithmetic mean, standard deviation, standard error of mean, minimum and maximum values, median, percentiles with 0.025 and 0.975 levels was calculated for trace element contents in normal prostate tissue. The reliability of difference in the results between the age groups was evaluated by Student's t-test. For the estimation of the Pearson correlation coefficient between different pairs of $U$ with other trace element mass fractions in the normal prostate tissue the Microsoft Office Excel program was also used.

\section{Results and Discussion}

\section{Validation methods}

In accordance with reported data ${ }^{[18]}$, mean U mass fraction in the prostate tissue $(0.4 \mathrm{mg} / \mathrm{kg}$ on dry mass basis) was almost one order of magnitude higher than the detection limit (DL) of INAA for this trace element in bone $(0.07 \mathrm{mg} / \mathrm{kg}$ of dry tissue $)^{[31,34]}$. However, mass fraction of $U$ in all prostate samples measured by us using INAA was under DL of U $(0.05 \mathrm{mg} / \mathrm{kg}$ of dry tissue).

Accurate determination of trace element concentrations by ICP-MS requires the use of a directly matrix-matched standard, with a similar major chemical composition and mineralogical form to the sample. However, no current standard allows for the quantification of $U$ in prostate or another human tissue. For this reason, we were forced to evaluate the accuracy of our method using other certified reference materials with the biological matrix, certified for the U contents - CRM INCT-MPH-2 Mixed Polish Herbs. Table 1 depicts our data for $U$ mass fractions in samples of certified reference material and the certified value of this material. The detected mean for the $U$ content $(M \pm S D)$ in the certified reference material Mixed Polish Herbs INCTMPH-2 obtained in this work was in good agreement with the mean of certified value (Table 1). This indicates an acceptable accuracy of the results on the $U$ content in the intact prostate samples.

Table 1: ICP-MS data of $U$ content $(M \pm S D)$ in Certified Reference Material Mixed Polish Herbs INCT-MPH-2 (mg/kg on dry mass basis).

\begin{tabular}{|l|l|l|}
\hline Certified Reference Material & Certificate & This work result \\
\hline Mixed Polish Herbs INCT-MPH-2 & 0.049 & $0.050 \pm 0.008$ \\
\hline
\end{tabular}

$\mathrm{M}$ - arithmetic mean; SD - standard deviation

\section{Increase of $U$ mass fractions in prostate with age}

Figure. 1 shows individual data for the U mass fraction in the prostate tissue for all samples and lines of trend with age. To estimate the effect of age on the $U$ content in prostate (Table 2) we examined three age groups: the first comprised a younger group with ages from 13 to 20 years (mean age 16.3 years, $n=9$ ), the second comprised men with ages ranging from 21 to 40 years (mean age 30.4 years, $n=28$ ) and the last one comprised older persons with ages ranging from 41 to 60 years (mean age 49.6 years, $n=27$ ). Table 2 represents certain statistical parameters (arithmetic mean, standard deviation, standard error of mean, minimum and maximum values, median, percentiles with 0.025 and 0.975 levels) of the $U$ content in prostate tissue of every age group. The results for all subjects from 13 to 60 years, taken together $(\Sigma)$, are also shown in Table 2 . a

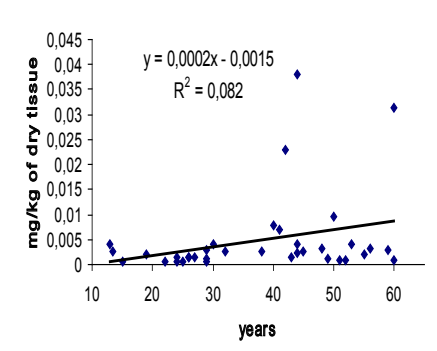

b

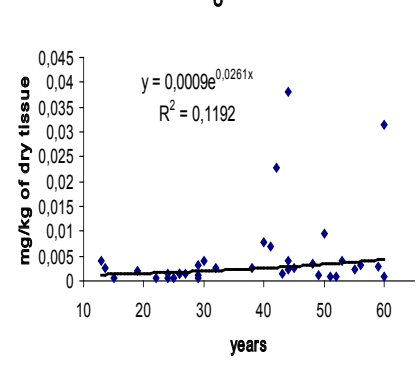

Figure 1: Individual mass fraction of $U$ in non-hypertrophic prostate of healthy men and trend lines ( $\mathrm{a}$-linear, $\mathrm{b}$ - exponential)

Mean value of the $U$ mass fraction in all prostate samples investigated in the study was $0.0049 \mathrm{mg} / \mathrm{kg}$ on dry mass basis (Table 2). The obtained mean for U mass fraction in human prostate are nearly two orders of magnitude lower than the only value of previously reported data ${ }^{[18]}$, one order of magnitude lower than the DL of INAA $(0.05 \mathrm{mg} / \mathrm{kg}$ of dry tissue), and 50 times higher than the DL of ICP-MS $(0.0001 \mathrm{mg} / \mathrm{kg}$ of dry tissue).

Statistically significant ( $\mathrm{p} \leq 0.05, \mathrm{t}$ - test) an age-related increase in $\mathrm{U}$ content was observed in age group from 41 to 60 years old (Table 3 ). As shown the data in Table 3, the average content of $U$ in the prostate gland of men under 20 years is almost 4 times lower than in the prostate of men over than 40 years. Such great increase in the $U$ content with age may be harmful to prostate's health. The U content remains at a constant level from puberty until 40 years and than begins to increase. Age-dependent increase of mass fraction of $U$ in the prostate is more ideally fitted by an exponential law than by a linear law (Fig. 1). However, the regression parameters $\left(\mathrm{R}^{2}\right)$ for $U$ are very low and differences between laws are not significant. Experimental values in Fig. 1 are so dispersed that it is very audacious

Table 2: Some statistical parameters of U mass fraction ( $\mathrm{mg} / \mathrm{kg}$ on dry mass basis) in the non-hypertrophic prostate tissue of healthy men

\begin{tabular}{|l|l|l|l|l|l|l|l|l|l|}
\hline Age group & Year & M & SD & SEM & Min & Max & Med & P0.025 & P0.975 \\
\hline 1 & $13-20$ & 0.00228 & 0.00134 & 0.00069 & 0.00070 & 0.00400 & 0.00222 & 0.00079 & 0.00389 \\
\hline 2 & $21-40$ & 0.00210 & 0.00193 & 0.00052 & 0.00054 & 0.00770 & 0.00137 & 0.00059 & 0.00652 \\
\hline 3 & $41-60$ & 0.00767 & 0.01117 & 0.00263 & 0.00079 & 0.03811 & 0.00297 & 0.00087 & 0.03527 \\
\hline$\Sigma$ & $13-60$ & 0.00491 & 0.00837 & 0.00139 & 0.00054 & 0.03811 & 0.00235 & 0.00067 & 0.03227 \\
\hline
\end{tabular}

$\mathrm{M}$ - arithmetic mean, SD - standard deviation, SEM - standard error of mean, Min - minimum value, Max - maximum value, Med- median, P0.025 - percentile with 0.025 level, P0.975 - percentile with 0.975 level, $\Sigma=1+2+3$. 
to derive a mathematical law and to draw a conclusion. However, if an exponential increase of $U$ in the prostate of healthy people will be confirmed, this could be interpreted as the result of a global increase of the concentrations of $U$ in the environment.

Table 3: Effect of age on mean values of $U$ content in human non-hypertrophic prostate

\begin{tabular}{|c|c|c|c|c|c|}
\hline \multicolumn{2}{|c|}{ Ratio of U mass fraction in different age groups } & \multicolumn{3}{|c|}{ Student's $t$-test $\mathrm{p}$} \\
\hline $\begin{array}{c}\text { Group II/ } \\
\text { Group I }\end{array}$ & $\begin{array}{c}\text { Group III/ } \\
\text { Group I }\end{array}$ & $\begin{array}{c}\text { Group III/ } \\
\text { Group II }\end{array}$ & I - II & I - III & II - III \\
\hline 0.92 & 3.36 & 3.65 & NS & $\leq 0.05$ & $\leq 0.05$ \\
\hline
\end{tabular}

$\mathrm{M}$ - arithmetic mean, SEM - standard error of mean, NS - non significant

\section{Human prostate as a biological material for environmental monitoring of $\mathbf{U}$}

Mean mass fraction of $U$ in the human prostate is at least few times higher than mean values of element content in the bone, skeletal muscle and liver (Table 4). The obtained mean for $\mathrm{U}$ mass fraction in human prostate are nearly two orders of magnitude higher than mean values of element content in the whole blood. Thus, we can conclude that the prostate is a target organ for $\mathrm{U}$ in human body and can be used as a biological material for environmental monitoring of $U$.

Table 4: A comparison between the mean $U$ content in the non-hypertrophic prostate and in bone, skeletal muscle, liver, and whole blood $(\mathrm{mg} / \mathrm{kg}$ on dry mass basis)

\begin{tabular}{|c|c|c|c|c|c|c|c|c|}
\hline $\begin{array}{c}\text { This } \\
\text { work }\end{array}$ & \multicolumn{4}{|c|}{ Tissue } & \multicolumn{5}{c|}{ Ratios } \\
\hline $\begin{array}{c}\text { Pros- } \\
\text { tate I }\end{array}$ & $\begin{array}{c}\text { Rib }^{[31,34]} \\
\text { II }\end{array}$ & $\begin{array}{c}\text { Muscle }^{[18]} \\
\text { III }\end{array}$ & $\begin{array}{c}\text { Liver }^{[35]} \\
\text { IV }\end{array}$ & $\begin{array}{c}\text { V Blood } \\
{[35]}\end{array}$ & $\begin{array}{c}\text { I/ } \\
\text { II }\end{array}$ & $\begin{array}{c}\text { I/ } \\
\text { III }\end{array}$ & $\begin{array}{c}\text { I/ } \\
\text { IV }\end{array}$ & I/V \\
\hline 0.0049 & 0.0014 & 0.00095 & 0.0010 & 0.000016 & 3.5 & 5.1 & 4.9 & 306 \\
\hline
\end{tabular}

In our study all the deceased were citizens of Moscow. None of those who died a sudden death had suffered from any systematic or chronic disorders before and had contact with $U$ in work places. Thus, our data may serve as an indicative normal values - 'natural' background level of U content in human prostate.

Table 5: Intercorrelations ( $r$ - coefficient of correlation) of the U content with other trace element contents in the non-hypertrophic human prostate gland

\begin{tabular}{|c|c|c|c|c|c|c|c|}
\hline Element & $r$ & Element & $r$ & Element & $r$ & Element & $r$ \\
\hline $\mathrm{Ag}$ & 0.074 & $\mathbf{C r}$ & $\mathbf{0 . 3 9 1}$ & $\mathrm{Mn}$ & -0.054 & $\mathrm{Se}$ & -0.136 \\
\hline $\mathrm{Al}$ & -0.186 & $\mathbf{C s}$ & $\mathbf{0 . 4 2 3}$ & $\mathrm{Mo}$ & $\mathbf{0 . 4 6 4}$ & $\mathrm{Si}$ & -0.178 \\
\hline $\mathrm{Au}$ & 0.013 & $\mathbf{C u}$ & $\mathbf{0 . 3 5 0}$ & $\mathrm{Na}$ & 0.197 & $\mathrm{Sm}$ & -0.145 \\
\hline $\mathrm{B}$ & 0.031 & $\mathrm{Dy}$ & -0.154 & $\mathrm{Nb}$ & 0.148 & $\mathrm{Sn}$ & $\mathbf{0 . 5 2 4}$ \\
\hline $\mathrm{Ba}$ & 0.161 & $\mathrm{Er}$ & -0.110 & $\mathrm{Nd}$ & -0.115 & $\mathrm{Sr}$ & 0.216 \\
\hline $\mathrm{Be}$ & $\mathbf{0 . 4 5 1}$ & $\mathrm{Fe}$ & 0.186 & $\mathrm{Ni}$ & 0.198 & $\mathrm{~Tb}$ & -0.180 \\
\hline $\mathrm{Bi}$ & -0.022 & $\mathrm{Gd}$ & -0.135 & $\mathrm{P}$ & 0.013 & $\mathrm{Th}$ & -0.109 \\
\hline $\mathrm{Br}$ & 0.071 & $\mathrm{Hg}$ & 0.065 & $\mathrm{~Pb}$ & -0.009 & $\mathrm{Tl}$ & -0.151 \\
\hline $\mathrm{Ca}$ & 0.222 & $\mathrm{Ho}$ & -0.170 & $\mathrm{Pr}$ & -0.097 & $\mathrm{Tm}$ & -0.124 \\
\hline $\mathrm{Cd}$ & 0.027 & $\mathrm{~K}$ & -0.155 & $\mathrm{Rb}$ & 0.091 & $\mathrm{Y}$ & -0.059 \\
\hline $\mathrm{Ce}$ & -0.074 & $\mathrm{La}$ & 0.145 & $\mathrm{~S}$ & -0.103 & $\mathrm{Yb}$ & -0.226 \\
\hline $\mathrm{Cl}$ & 0.203 & $\mathrm{Li}$ & -0.013 & $\mathrm{Sb}$ & 0.184 & $\mathrm{Zn}$ & 0.129 \\
\hline $\mathrm{Co}$ & 0.011 & $\mathrm{Mg}$ & -0.056 & $\mathrm{Sc}$ & 0.046 & $\mathrm{Zr}$ & -0.014 \\
\hline
\end{tabular}

statistically significant values with $\mathrm{p} \leq 0.01$ are in bold

\section{Inter correlations of the $U$ content with other trace element}

Using data previously reported by as on trace element contents in human prostate ${ }^{[19-30]}$, a statistically significant $(\mathrm{p} \leq$ $0.01)$ direct correlation was found between the prostatic $U$ and $\mathrm{Be}(\mathrm{r}=0.45), \mathrm{U}$ and $\mathrm{Cr}(\mathrm{r}=0.39), \mathrm{U}$ and $\mathrm{Cs}(\mathrm{r}=0.42), \mathrm{U}$ and $\mathrm{Cu}(\mathrm{r}=0.35), \mathrm{U}$ and $\mathrm{Mo}(\mathrm{r}=0.46)$, and particularly between $\mathrm{U}$ and $\mathrm{Sn}(\mathrm{r}=0.52)$. No any inverse correlation was observed. It can mean that among trace elements there is no any significant antagonist of the $\mathrm{U}$ intake in human body.

\section{Conclusions}

The inductively coupled plasma mass spectrometry allows the determination of the contents of $U$ in prostate tissue of healthy adults with uncertainties under $10 \%$ and DL nearly $0.0001 \mathrm{mg} / \mathrm{kg}$ of dry tissue. Mean values $(\mathrm{M} \pm \mathrm{SEM})$ for the mass fraction of $U$ in prostate of all subjects taken together was $0.0049 \pm 0.0014 \mathrm{mg} / \mathrm{kg}$ of dry tissue. Mean values $(\mathrm{M} \pm \mathrm{SEM})$ for the mass fraction of $U$ in three age groups: 13-20 years (1), $21-40$ years $(2), 41-60$ years $(3)$ were $0.0023 \pm 0.0007,0.0021$ \pm 0.0005 , and $0.0077 \pm 0.0026 \mathrm{mg} / \mathrm{kg}$ of dry tissue, respectively. Statistically significant ( $\mathrm{p} \leq 0.05$, $\mathrm{t}$ - test) and exponential increase of the $U$ content in prostate tissue with age was observed. It was shown also that the $U$ content in the human prostate is higher than a level of element content in the bone, skeletal muscle, liver, and whole blood. Thus, the prostate is a target organ for $\mathrm{U}$ in human body and can be used as a biological material for environmental monitoring of U. No significant antagonist of the $\mathrm{U}$ in prostate tissue was found.

\section{Acknowledgments}

The authors are grateful to the late Prof. A.A. Zhavoronkov, Institute of Human Morphology, Russian Academy of Medical Sciences, Moscow, for supplying prostate specimens. We are also grateful to Dr. Karandaschev V., Dr. Nosenko S., and Moskvina I., Institute of Microelectronics Technology and High Purity Materials, Chernogolovka, Russia, for their help in ICP-MS analysis.

\section{Reference}

1. Todorov, P.T., Ilieva, E.N. Contamination with uranium from natural and anthropological sources. (2006) Rom J Phys 51(1-2): 27-34.

2. IAEA. Environmental contamination from uranium production facilities and their remediation. Proceedings of an International Workshop (Lisbon, 11-13 February 2004). (2005) International Atomic Energy Agency, Vienna.

3. Wasserman, H., Solomon, N., Alvarez, R., et al. Killing our own. Chronicling the Disaster of America's Experience with Atomic Radiation, 1945-1982. (1982) Dell Publishing Co., Inc.

4. Cragle, D.L., McLain, R.W., Qualters, J.R., et al. Mortality among workers at a nuclear fuels production facility. (1988) Am J Ind Med 14(4): 379-401.

5. Loomis, D.P., Wolf, S.H. Mortality of workers at a nuclear materials production plant at Oak Ridge, Tennessee, 1947- 1990. (1996) Am J Ind Med 29(2): 131-141.

6. Ritz, B. Radiation exposure and cancer mortality in uranium processing workers. (1999) Epidemiology 10(5): 531-538.

7. Dupree-Ellis, E., Watkins, J., Ingle, J.N., et al. External radiation exposure and mortality in a cohort of uranium processing workers. (2000) Am J Epidemiol 152(1): 91-95.

8. Guseva Canu, I., Dupree Ellis, E., Tirmarche, M. Cancer risk in ucle- 
ar workers occupationally exposed to uranium - emphasis on internal exposure. (2008) Health Phys 94 (1): 1-17.

9. McGeoghegan, D., Binks, K. The mortality and cancer morbidity experience of workers at the Capenhurst uranium enrichment facility 1946-95. (2000) J Radiol Prot 20(4): 381-401.

10. Ritz, B., Morgenstern, H., Crawford-Brown, D., et al. The effects of internal radiation exposure on cancer mortality in nuclear workers at Rocketdyne/Atomics International. (2000) Environ Health Perspect 108(8): 743-751.

11. Boice, J.D., Cohen, S.S., Mumma, M.T., et al. Mortality among radiation workers at Rocketdyne (Atomics International), 1948-1999. (2006) Radiat Res 165(1): 98 -115.

12. Beral, V., Inskip, H., Fraser, P., et al. Mortality of employees of the United Kingdom Atomic Energy Authority, 1946-1979. (1985) BMJ (Clin Res Ed) 291(6493): 440-447.

13. Carpenter, L.M., Higgins, C.D., Douglas, A.J., et al. Cancer mortality in relation to monitoring for radionuclide exposure in three UK nuclear industry workforces. (1998) Br J Cancer 78(9): 1224-1232.

14. Zhu, K., Devesa, S.S., Wu, H., et al. Cancer Incidence in the U.S Military Population: Comparison with Rates from the SEER Program. (2009) Cancer Epidemiol Biomarkers Prev 18(6): 1740-1745.

15. Fisenne, I.M., Perry, P.M., Harley, N.H. Uranium in humans. (1988) Radiat Prot Dosimetry 24(1-4): 127-131.

16. Singh, N.P. Thorium, uranium and plutonium in human tissues of world-wide general population. (1990) J Radioanal Nucl Chem 138(2): 347-364.

17. Li, W.B., Roth, P., Wahl, W., et al. Biokinetic modeling of uranium in man after injection and ingestion. (2005) Radiat Environ Biophys 44(1): 29-40.

18. Iyengar, G.V., Kollmer, W.E., Bowen, H.J.M. The Elemental Composition of Human Tissues and Body Fluids. A Compilation of Values for Adults. (1978) Verlag Chemie, Weinheim. 151.

19. Zaichick, S., Zaichick, V. INAA application in the age dynamics assessment of $\mathrm{Br}, \mathrm{Ca}, \mathrm{Cl}, \mathrm{K}, \mathrm{Mg}, \mathrm{Mn}$, and $\mathrm{Na}$ content in the normal human prostate. (2011) J Radioanal Nucl Chem 288(1): 197-202.

20. Zaichick, S., Zaichick, V. The effect of age on Ag, Co, Cr, Fe, Hg, $\mathrm{Sb}, \mathrm{Sc}, \mathrm{Se}$, and $\mathrm{Zn}$ contents in intact human prostate investigated by neutron activation analysis. (2011) Appl Radiat Isot 69(6): 827-833.

21. Zaichick, S., Zaichick, V. The Br, Fe, Rb, Sr, and Zn content and interrelation in intact and morphologic normal prostate tissue of adult men investigated by energy dispersive X-ray fluorescent analysis. (2011) X-Ray Spectrom 40(6): 464-469.

22. Zaichick, V., Nosenko, S., Moskvina, I. The effect of age on 12 chemical element contents in intact prostate of adult men investigated by inductively coupled plasma atomic emission spectrometry. (2012) Biol Trace Elem Res 147(1-3): 49-58.
23. Zaichick, S., Zaichick, V., Nosenko, S., et al. Mass Fractions of 52 Trace Elements and Zinc Trace Element Content Ratios in Intact Human Prostates Investigated by Inductively Coupled Plasma Mass Spectrometry. (2012) Biol Trace Elem Res 149(2): 171-183.

24. Zaichick, V., Zaichick, S. The effect of age on $\mathrm{Br}, \mathrm{Ca}, \mathrm{Cl}, \mathrm{K}, \mathrm{Mg}$, $\mathrm{Mn}$, and $\mathrm{Na}$ mass fraction in pediatric and young adult prostate glands investigated by neutron activation analysis. (2013) Appl Radiat Isot 82: 145-151.

25. Zaichick, V., Zaichick, S. INAA application in the assessment of $\mathrm{Ag}, \mathrm{Co}, \mathrm{Cr}, \mathrm{Fe}, \mathrm{Hg}, \mathrm{Rb}, \mathrm{Sb}, \mathrm{Sc}, \mathrm{Se}$, and $\mathrm{Zn}$ mass fraction in pediatric and young adult prostate glands. (2013) J Radioanal Nucl Chem 298: 1559-1566.

26. Zaichick, V., Zaichick, S. NAA-SLR and ICP-AES Application in the assessment of mass fraction of 19 chemical elements in pediatric and young adult prostate glands. (2013) Biol Trace Elem Res 156(1-3): 357-366.

27. Zaichick, V., Zaichick, S. Use of neutron activation analysis and inductively coupled plasma mass spectrometry for the determination of trace elements in pediatric and young adult prostate. (2013) AJAC 4(12): 696-706.

28. Zaichick, V., Zaichick, S. INAA application in the assessment of chemical element mass fractions in adult and geriatric prostate glands. (2014) Appl Radiat Isot 90: 62-73.

29. Zaichick, V., Zaichick, S. Determination of trace elements in adults and geriatric prostate combining neutron activation with inductively coupled plasma atomic emission spectrometry. (2014) Open J Biochem1(2): 16-33.

30. Zaichick, V., Zaichick, S. Use of INAA and ICP-MS for the assessment of trace element mass fractions in adult and geriatric prostate. (2014) J Radioanal Nucl Chem 301: 383-397.

31. Zaichick, V., Zaichick, S. Instrumental neutron activation analysis of trace element contents in the rib bone of healthy men. (2009) J Radioanal Nucl Chem 281: 47-52.

32. Zaichick, S., Zaichick, V. Human bone as a biological material for environmental monitoring. (2010) Int J Environ Health 4(2-3): 278-292.

33. Zaichick, S., Zaichick, V., Karandashev, V., et al. The effect of age and gender on 59 trace element contents in human rib bone investigated by inductively coupled plasma mass spectrometry. (2011) Biol Trace Elem Res 143(1): 41-57.

34. Zaichick, V. Chemical elements of human bone tissue investigated by nuclear analytical and related methods. (2013) Biol Trace Elem Res 153(1-3): 84-99.

35. Iyengar, G.V. Reevaluation of the trace element content in reference men. (1998) Radiat Phys Chem 51(4-6): 545-560.
Ommega Online Publishers

Journal Title: Journal of Environment and Health Science (JEHS)

Journal Short Name: J Environ Health Sci
Journal ISSN: 2378-6841

E-mail: environmentalscience@ommegaonline.org

Website: www.ommegaonline.org 